\title{
TWO PAGES FROM THE CULTURE OF THE DOUBLE SPEECH AND OF TACIT SUPPOSITIONS
}

\begin{abstract}
The power relations - at the time of Erasmus and Mandeville, and also in the present - make the critique of the status quo to be very difficult. An answer to this situation was and is the complex of the double speech and tacit political suppositions. The paper suggests some similarities between the texts of the above-mentioned thinkers and, on the other hand, the present mainstream political jargon, by emphasising the differences rather: it is noteworthy that Mandeville and Erasmus had a strong, while indirect through their humoristic use of the double speech, critique of the state of things described by them.

The conclusions developed here concern the tacit suppositions in the political discourse and how the two items are perennial within the modern culture.

Keywords: double speech, tacit suppositions, Erasmus, Mandeville, present political discourse.

Precautions

First of all, my paper uses two expressions which have different senses in linguistics and in philosophy. To say it frankly, even though in linguistics they correspond in a quite clear manner to the intentions of thoughts behind the speeches, and are marked within the frame of grammar and rhetoric, so although without the description of the forms which can be grasped and understood we could not pervade into the depth of the human mind, just philosophy is which does question the content of the linguistic (and not only linguistic) manifestations. Philosophy was first, even if linguistics describes that which is obviously first of all. But I want not incite a superfluous quarrel: was he not, Lazar Şăineanu, quite long before the Western raising of the idea of interdisciplinary approach, one of

the firsts who stressed that philology would be philosophy (Eliade, 1898, p. 408) ${ }^{1}$ ?

The first expression is double speech. For my intention is to discuss about the political significance of some early philosophical discourses of the modernity - as mirror of the present political jargon, I do not focus on the technical linguistic aspects of dialogues, for example on the difference between the actual words spoken, as direct speech, mentioned inwards the indirect "neutral" narrative, or the incidental proposition. For me, double speech means the expression of two different intentions of a single speaker; the intentions correspond to different worldviews, and the expression as

Citing Lazăr Şăineanu, Istoria filologiei române, 1895 [History of the Romanian philology]: "philology is understood in the German sense as the science of all the manifestations of the thinking of a certain people".
\end{abstract}


such aims to mystify the real beliefs of the speaker. If in linguistic analysis, as I dare to say I understood, we are witnessing the coexistence of the same intentions to clarify the expressions of the facts, through both the direct and indirect speech, in politics - as philosophy has from long ago insisted - there are opposite intentions. There is also another distinction. The linguistic expression of the double speech emphasises two temporal (and special) moments: the one of the speakers cited by the narrator, and the one of the narrative (narrator) itself. While in politics, there is only one temporal moment: in the slogans the speaker waves within his/her discourse, and in the intentions grasped by the listeners despite all the sophisticated means to cover them; as we all know, "there would not be possible to lie all the people twice/many times". Or would it? Are the real intentions of the speaker really grasped by the listeners? Well, and even though this is not the place to elaborate on this topic - see the savage criminalisation of "fake news" just by those who do not want their intentions be understood by the broad masses, i.e. to understand alternative views towards those of the ruling strata the listeners are intuiting at least some real intentions: as it is statistically proven.

The other expression is tacit suppositions. This time, there is a similarity between linguistics and politics. As there are common sense views on languages - which linguists in all theirs variants unveil - there are tacit suppositions in politics. Let me not continue with linguistic connaissances livresques. But to say that if in linguistics a common sense supposition is within the pattern of Monsieur Jourdain, the one of the acquisition of the language following the model of the experience of children - as it was shown in the psycholinguistic approach (Karlsson, 2007) - in politics the most important and gene- ral tacit supposition is that of the emperor (who) has no clothes, as Hans Christian Andersen formulated it.

The third notion mentioned by the title of this paper is culture. I certainly shall not plunge into the traps of the definitions and cultural mentalities surrounding this concept. I simply put - and this is my, now explicit presupposition - that a society where the common beliefs, even though mostly tacit, are deduced from the supposition of the inherent subordination toward a "political class" which has no clothes is a society whose political culture is deeply alienated. With the entire cultural creation in sciences and arts, in institutions and organisations, in labour, entertainment and conduct of sentiments, the political culture of the above-mentioned tacit supposition strongly influences the whole life of people: there is no real autonomy of culture since people feel alienated and their alienation without any hope of mastering and surpassing alienation and its social causes. Thus the characteristic of culture I wanted to stress on is the one imprinted by the politics based on the tacit supposition of the "inherent" political double speech.

I shall now briefly discuss a premise of the specific model of critique of the power relations as it was constituted in Erasmus' and Mandeville's famous works.

\section{The Warning of the Clown}

For disenchanting the power relations, one has to note their difference from the relations of authority: while these one consist in recognition of the competence people have in their social functions - within the "technical" division of the social labour, thus the authority being a "technical" measurement - the power is relation of 
domination and submission. The idea that power and authority would be equivalent - thus that the powerful would be inherently "technically" competent, i.e. ruling and administrating with the best consequences for the biggest number of population and for present and future - is only the result of the power relations, and was and is constituted in their frame, thus imposed by the ruling strata. And by saying that "there is certainly a technical, but also a political competence" considering the latter as presence in the ruling, political and economic, circles and ability to manoeuvre so as to keep the personal and group power, while in the same time emitting specious discourses - these circles of power once more prove the difference between ("technical") authority and political power/power of domination in favour of restrictive interests.

Generated by historical conditions of rarity and weak means of production, power has developed as a holding of these means and of the means to impose this holding. These second means were, from the beginning, material and spiritual: the physical force and the weapons, the knowledge, the ideologies of domination. These ideologies have created the force of the authority of domination: the strong beliefs of the eternity, normality and functionality of the power relations and their holders.

It's no wonder that the critique of this status quo was so difficult that it represented mere exceptions. But as nobody was ever asked for when one imposed his/her submission, with the rise of modern relationships thinkers began to question this state of things: the extraordinary aspect was not the fact of the rebellion, but just of the submission of the many (de La Boétie, 1987).

In this context, the European Middle Age witnessed the apparition of a person whose function allowed him - there were only males to criticise the establishment and the lords, without punitive consequences. He was the Clown or the Madman. His strategy was to legitimise and at the same time annul the weight of his critical speech with the characterisation of insanity. In this way, the intention of critique and the fact to submit reality to the requirements of reason, so to the truth, constituted the core of the discourse of the Madman. But even though this discourse was constructed in a figurative sense, it was heard in the proper sense by those who were not "the emperor without clothes"; while "the emperor" heard the form of the intention of critique as a joking manner to humour him, to submit to him: au fond, he was so powerful that some flying words could not destroy his cocoon of comfort.

The double speech of the Madman was just the coexistence of the two messages he emitted: the one of submission to the lord, through jokes and exercises of admiration; the other of critique. The coexistence as such of these types of discourses emphasised the contempt behind the jokes, transforming these into a figurative manner of the manifestation of scorn, while the critical discourse could suggest the proper sense of rebel courage discovered by the human reason.

The state of things described by Andersen's story, The Emperor's New Clothes (1837) emphasised that the double speech was not the specifics of some special people, but of the society as a whole. People expressed what they did not believe, while believing what they could not say. Only sometimes and someones dared to infringe the unspoken rule of the social behaviour: the Child from the tale is a beautiful and optimistic form of the old Madman. The culture of double speech was thus strongly related to the tacit supposition of the necessary ambiguous social behaviour, slyness and exteriority to 
the moral principles, just for the sake of the short existence and non-suffering.

This situation was so dramatic that even the thinkers were determined to create within the pattern of the double speech.

\section{Examples and Directions}

Erasmus of Rotterdam wrote his The Praise of Folly (Stultitiae Laus, 1509) just in the manner of a discourse of the Madman. In the very Renaissance where the modern spirit manifested through the need to change at least by alleviating the manners, this need could not happen. Thus Folly, or Madness, was that who criticised the princes and kings, the priests, the companions, the flattery and corruption, the war and cruelty, the irrational manner of living (Erasmus, 1511). In front of all of them, not reason could preserve the human felicity, but "folly": "Let him that will compare the benefits they receive by me". "Folly is the only thing that keeps youth", and happiness: on the contrary, the search of the reasons of facts made people the possibly unhappier. In any case, this was the conclusion for those who governed: "Who, being a fool himself, may the better know how to command or obey fools". But for all, it would have been better to ignore, and to hope: so, just reason made all to feel being unhappier than they might think about themselves before, unhappier animals not reconciling with their own destiny.

Erasmus has aimed just to evocating, in the indirect manner of the standpoint of Folly, this irrationality, against which Descartes, over more than one hundred years, was to be to write in a direct speech his guidebook of a rational method.

The speech of Erasmus was double: the reasonable moderate author (Erasmus) could not but "wonder" about the very facts Folly put into light. At the same time, Folly was the one who represented the humanist, critical and reformist side of Erasmus. At another level, if only Folly could think to reject so many usual habits - so to change them (she was Folly), this meant that it was a sign of insanity to live in so irrational structures which required so irrational behaviours: she was wiser than those who covered the reality in the shadow of the tacit suppositions of conformism. From a standpoint, to be opportunistic meant to be integrated within the specific social (ir)rationality; from another, to be opportunistic meant only to fortify the irrationality within which one was to no more could live.

The other thinker mentioned here is Bernard of Mandeville. As usually is known, he stressed the interdependence - within the division of labour and occupations in the modernising society - of vices and virtues (of Mandeville, 1705) ${ }^{2}$ : "Thus Vices nursed Ingenuity", "Bare Virtue can't make Nations live", "yet live in Ease Without great Vices, is a vain Eutopia seated in the Brain". But even though the main message was the inherence of the subordination towards the powerful and the pattern of a society where "whilst Luxury/ Employ'd a Million of the Poor" - since the needs of people could no more be satisfied with the Acorns presumably eaten in the Golden Age (of Mandeville, 1705) ${ }^{3}$, and the development of means to live in a more human and happier way was dependent just on the cultural needs which were social and socially generated (of Mandeville, 1705) ${ }^{4}$ - the

\footnotetext{
2 "Thus every Part was full of Vice, / Yet the whole Mass a Paradice".

"They, that would revive/ A Golden Age, must be as free,/ For Acorns, as for Honesty".

4 "Millions endeavouring to supply/ Each other's Lust and Vanity".
} 
realisation as such of this message was the result of a harsh social critique.

This critique was a mixture between the position of a rationalist intellectual - so even though rationalist, part of a privileged class which thought that the opposition between the physical and the intellectual labour would be eternally specific to the "human nature" and thus which was not confident in the popular classses and an optimistic liberal. Rationalism imposed to respond to those who opposed to the funerals of the idealistic bourgeois revolution through the "glorious revolution" of 1688 , and who signalled the continuity of the social polarisation (which meant and means poverty and suffering). Liberalism demanded to found this continuity within the pattern of the "human nature" and the organic interdependence of the rich and the poor "for the sake of the whole", where nevertheless the voice of the latter was ignored. There is a difference between the liberal belief at the time of Cromwell - when the main objective being the taking of the political power, the economical problems could be veiled under the idea of the postponement and resolution in the victorious future - and the liberal conviction expressed by Mandeville, after the "glorious revolution", when the former idealism could but be substituted by the need to support the status quo.

But Mandeville's critique - mostly, of the hypocrisy covering the real facts - was also a response to the rationalist tradition of the modern standpoint. There were "Sharpers, Parasites, Pimps, Players, Pick-Pockets, Coiners, Quacks, Sooth-Sayers", lawyers and physicians who used their position to acquire more means for a happy life. There were so many frauds (of Mandeville, $1705)^{5}$ that one of the most important preoccupations of the new bourgeois rule in England be- came just the limitation of the power of the bureaucratic strata. Certainly, it was about capitalism "in a country" - if I can use the tern coined by Trotsky concerned "socialism in a single country" - on the expense and domination of other countries, but what was important was the model thought to be the best, so useful to generalise it: "Fraud, Luxury, and Pride must live/ Whilst we the Benefits receive".

Where is here the double speech? It is in the coexistence of critique and the legitimating of the "really existing capitalism" within the same direct discourse. There are no different supposed speakers - as in Erasmus - but only one, who does not know what to do with the social antagonisms: he criticises, and he resigns himself. But in Mandeville, as in Erasmus, one can hear two voices, irrespective of their bearers.

In both Erasmus and Mandeville we can observe the conscience of the presence of the categories without rights, except to shut up in the shadow of the "folly". Both Erasmus and Mandeville reflect the adversity towards the imperative of social conformism. And both of them stress the commandment of carpe diem: it's so sweet to know, to forget, to taste the everyday pleasure, to wait the life passing, to savour the own uniqueness, to illusion! What else to do?

The two representatives of the beginning of the modern thinking constitute inter alia a model of the double speech of the intellectuals. Not they were guilty of the later development of this model: there are the historical conditions first of all, the level of the productive forces - as well as the personal will to win the comfortable opportunist behaviour, which have to be questioned. But indeed the intellectual prestige of the two great thinkers had only strengthened the model of double speech as normal reaction

5 "But who can all their Frauds repeat!" 
of politicians and common people in front of the power relations.

Finally here, the humoresque manner to cover the need to say the truth, so to speak in the proper sense of the word - common to intellectuals and ordinary people - was, and is, the sign and form of the manifestation of the instinct of conservation. This instinct demands to use the figurative sense of the word, thus to hide oneself behind some abstract personages who could never be hurt.

\section{The "epigones"}

I want to conclusion here only by mentioning that the double speech of the present political jargon no longer presents any heroic appearance. There are no sincere tendencies of social critique: if Erasmus and Mandeville deeply thought that the social problem is so important that they must follow the purpose of explaining it, if not to also alleviate it, if they (although moderate thinkers with mostly a liberal perspective) openly ${ }^{6}$ criticised the state of things, in the present political discourses the selfish interest to keep one's political position and to fight for power is so evident, the impression of falsehood when the pity and philanthropy are scattered through openly shameful corrupt practices, that the result is demagogue discourses full of promises and big words as 'democracy' and 'the people', and not at all real care for the others in the concrete meaning of this last word as everyone and all the human beings.

There is no in present a classical double speech as sign of multiplication of the selftaking place at the same time: in the explicit form of the speech of the rebellion, of the social

6 They did that open critique even though they used the technique of double speech. critique, and in the explicit form of social obedience. No, the present political double speech expresses rather one explicit discourse - a double, sheer nonsense about the most important problem: how democracy is "of the people, by the people and for the people" (Abraham Lincoln), but having behind it the implicit murmur of the voice everyone can hear: "Oh, I am so bored of all of these" -. Erasmus and Mandeville expressed two kinds of convictions. In the present political speech is only one.

I think that if we speak about the double speech of the present political jargon (Dauzat 1929 , p. 21$)^{7}$, we have in mind the two intentions expressed: the one for voters, the political public, and the other for the pares.

In the present political discourses, there is only one voice, and not two, which insists on the rights of the powerful as exceeding just the democratic values which were put as the basis of the modern social consensus. The only political voice supports restrictive interests: it waves the democratic values, but it expresses the right to infringe them - and without punishment -, it considers in a pharisaic manner that everyone in the people has to sacrifice himself /herself, but someones being excepted, it insists on the concentration of the political voice as being representative of the public voices. And it is not about an explicit totalitarian regime: only that the present multi-party system converges toward the single respectable neo-liberal pensée unique. The old liberal illusion of the necessity and possibility to fight for the right of the political enemy to express his/her opinion ${ }^{8}$ tends to be forgotten and

7 As means of ,cohesion of closed groups, a reaction against the external agents and if necessary a body of protection".

8 "I disapprove of what you say, but I will defend to the death your right to say it", (Tallentyre, 1906, p. 199). 
surpassed: the powerful have more power than ever and, at the same time, they are facing their crisis. This is the reason of the principle of double standards applied to the public discourse: freedom for the dominant ideological speech, non-freedom for the critical speech (Kumarasamy \& Grant, 2018). The "legitimated violence" and the strong manipulation are the counter-models of the rational political speech: indeed, "if you can't convince them, confuse them" (Truman, "Quotes").

The result of this type of political discourse is the decay of democracy: because of the lies behind and within the political discourses, people no longer trust either in the "political class" or in the democratic institutions and organisations as such. It will be an extinction rooted in apathy, indifference and - to not forget the real world processes - hunger and malnutrition. But maybe just this is what is more efficient for the owners of the power, is it? Once more, the double speech of Erasmus and Mandeville opened up an optimistic and, I have to underline, open path to the political discourse. The present double speech closes it.

\section{REFERENCES}

Dauzat, A. (1929). Les argots. Caractères. Évolution. Influence. Paris: Delgrave.

de La Boétie, É. (1987). Discours sur la servitude volontaire ou Contr'un. Genève: Librairies Droz.

Eliade, P. (1898). L'influence française sur l'esprit publique en Roumanie. Paris: Ernest Leroux, Libraire-Éditeur.
Erasmus, D. (1511). The Praise of Folly. (J. Wilson, Trans.; 1625-1695; 1668), Project Gutenberg. Retrieved October 14, 2018 from:

http://www.gutenberg.org/ebooks/9371.

Karlsson, F. (2007). Early Generative Linguistics and Empirical Methodology. In $\mathrm{M}$. Kytö, \& A. Lüdeling (Eds.), Handbook on Corpus Linguistics, pp. 1-17 . Berlin \& New York: Mouton de Gruyter. Retrived October 14, 2018 from: https://pdfs.semanticscholar.org/0968 /15884f03ee7d1729d31441513ccc9c 668699.pdf.

Kumarasamy, S., \& Grant, A. (2018). Canada: Student Protests Suppressed under Guise of Free Speech, 11 October. Retrieved October 14, 2018 from: http://www.marxist.com/canadastudent-protests-suppressed-underguise-of-free-speech.htm.

of Mandeville, B. (1705). The Grumbling Hive, or Knaves Turn'd Honest. Transcribed from the edition of 1705 , with short passages from the 1714 edition as The Fable of the Bees. J. Lynch (Ed.). Retrieved October 14, 2018 from: https://andromeda.rutgers.edu/ jlync h/Texts/hive.html.

Tallentyre, S. G. (Evelyn Beatrice Hall). (1906). The Friends of Voltaire. London: Smith Elder and Co.

Truman, S. H. Quotes. Retrieved October 14, 2018 from: https://www.brainyquote.com/author s/harry s truman. 